$502.4: 551.4 .035(477.8)$

\author{
- рус к, • оск люк \\ ьвівський н ціон льний університет імені в н \\ вул. . орошенк , 41, м. ьвів, 79000, кр їн, \\ e-mail: brusak_vitaliy@ukr.net,zolotynka@ukr.net
}

озглянуто можливість створення н території овтрів міжн родної к тегорії збереження геосп дщини - геоп рку. х р ктеризов но геолого-геоморфологічну будову території одільських овтрів т з зн чено особливо цінні геолого-геоморфологічні об'єкти, які ст нуть основою проектов ного геоп рку. од но перелік геотуристичних об'єктів досліджув ної території т з пропонов но шляхи розвитку пізн в льних форм туризму у меж х овтрів.

лючові слов : геолого-геоморфологічний об'єкт, геосп дщин, геоп рк, лоб льн мереж геоп рків, вропейськ мереж геоп рків, викопний риф, одільські овтри.

суч сному ет пі охорони природи проблем тиці збереження т інвент риз ції особливо цінних геолого-геоморфологічних об’єктів приділяють зн чну ув гу. ля підтримки т розвитку територій з цінними об'єкт ми геосп дщини (типовими т унік льними для конкретного регіону геологічними розріз ми, форм ми рельєфу, виход ми корінних порід тощо) н міжн родному рівні, згідно з рішенням икон вчого комітету , в червні 2001 p. (161 EX/Decisions, 3.3.1) з пров джено нову форму охорони природи - геоп рк $[10,11]$.

eon $\boldsymbol{p} \boldsymbol{\kappa}$ - територія 3 визн ченою геологічною сп дщиною і розробленою прогр мою (стр тегією) ст лого розвитку. оловні з вд ння геоп рків:

1) з хист геологічної сп дщини відповідно до чинного н ціон льного з конод вств . еоп рк повинен сприяти збереженню т охороні т ких об'єктів геосп дщини: репрезент тивних (типових) порід - стр тотипів, мінер льних ресурсів, місцепроявів рідкісних мінер лів, ск м'янілостей рослин і тв рин, форм рельєфу т л ндш фтів;

2) поширення інформ ції з т ких природничих дисциплін: геологія т гірнич спр в , інженерн геологія, структурн геологія, вулк нологія, седиментологія, стр тигр фія, мінер логія, петрологія, п леонтологія, геоморфологія, гляціологія, спелеологія, гідрологія, фізичн геогр фія, геогр фія грунтів.

рогр м розвитку геоп рків з тверджен у березні 1999 р. н енер льній конференції ідповідно до прогр ми, розробленої спільно з іжн родним союзом геологічних н ук т урядовими інституціями, геоп рки повинні привернути ув гу до цінності природних ресурсів емлі, необхідності збереження геологогеоморфологічної сп дщини для м йбутніх поколінь. основу діяльності геоп рків узято розвиток екологічного туризму, н родних промислів т принцип тісної співпр ці дміністр цій природоохоронних територій з місцевим н селенням [2, 11]. рогр м розвитку геоп рків повинн скоординув ти міжн родні т н ціон льні зусилля у сфері охорони особливо цінних геолого-геоморфологічних об'єктів. творено лоб льну ме-

(C) рус к ., оск люк ., 2012 
режу геоп рків (Global Geoparks Network (GGN)) т вропейську мережу геоп рків (European Geoparks Network (EGN)), які співпр цюють 3 ентром сесвітньої сп дщини , сесвітньою мережею біосферних резерв тів (The Man and the Biosphere Programme (MAB)), т кож 3 орг ніз ціями які з йм ються збереженням т охороною об'єктів геосп дщини $[1,10]$. зн чимо, що ст тус геоп рку отримують, з звич й, уже н явні природно-з повідні території (природні з повідники, н ціон льні природні п рки) з визн ченими цінними геолого-геоморфологічними об'єкТ ми. еоп рк не нов особлив к тегорія іжн родного союзу охорони природи (IUCN) чи природноз повідного фонду окремої кр їни. ін може зн чно відрізнятись від тр диційних з повідників т н ціон льних природних п рків, у яких основну ув гу приділяють охороні біоти окремих регіонів (н прикл д, фрик нські н ціон льні п рки).

ерспективними для створення геоп рків ув ж ють великоплощинні природно-з повідні території з об’єкт ми геолого-геоморфологічної сп дщини, які м ють унік льний $\mathrm{x}$ р ктер т є прив бливими для розвитку рекре ції. зв ним критеріям н теритоpiї кр їни відповід $є$ б г то регіонів, серед яких можн н зв ти і одільські овтри.

em дослідження - про н лізув ти суч сний ступінь охоплення охороною території одільських овтрів і цінних геолого-геоморфологічних об'єктів регіону, які є передумовою створення геоп рку, т кож з пропонув ти шляхи розвитку пізн в льних форм туризму в їхніх меж х.

території одільської височини є зн чн кількість особливо цінних геолого-геоморфологічних об'єктів: скелі, п горби-ост нці, печери, к рстові лійки т озер , водосп ди. собливо вир зно н тлі полого-хвилястого рельєфу одільської височини виділяються викопні рифові побудови міоцену, утворюючи один 3 н йм льовничіших кр євидів оділля. нік льність одільських овтрів зумовлен їхнім походженням т доброю збереженістю в суч сному рельєфі. тійкі рифові в пняки формують скельні виходи, річки, перетин ючи овтри, утворюють скелясті к ньйоноподібні долини. території овтрів збереглись цінні ділянки степової, лучно-степової т н скельно-степової рослинності.

озглянемо проект створення геоп рку н території одільських овтрів, розроблений згідно з з пропонов ним . іньком, . евчук (2011) пл ном. труктур опису проектов ного геоп рку є методичною розробкою в р мк х теми “ онцепту льні і методичні з с ди обгрунтув ння мережі геоп рків в кр їні” (номер держ вної реєстр ції 0110U001358).

г льн інформ ція про проектов ний геоп рк. роектов н під геоп рк територія розт шов н в меж х одільських овтрів - унік льного геолого-геоморфологічного утворення н території одільської височини. нік льність овтрів пов'яз н , поперше, з їхнім походженням - це викопні рифові побудови середнього міоцену, т , подруге, з доброю збереженістю і морфологічною вир женістю в суч сному рельєфі оділля. труктурно-денуд ційний рельєф овтрів, утворений ун слідок відпреп рув ння 6 денського 6 р'єрного рифу т с рм тських біогермів, $\epsilon$ рідкісним типом рельєфу 6 меж $x \quad \kappa p$ їни і ст новить зн чний інтерес для дет льних геолого-геоморфологічних досліджень.

дміністр тивним р йонув нням геоп рк розміщений н території ернопільської т мельницької обл стей кр їни. овтри простяг ються з північного з ходу н південний схід уздовж лінії ідк мінь ( ьвівськ обл.)- ї- озтоцькі- 6 р ж- к л тр сне- ичківці ( ернопільськ обл.)- в нківці- ишнівчик- м'янець- одільськийруг ( мельницьк обл.) м йже н 150 км. ежі геоп рку визн чені вже н явними н 
овтр х великоплощинними природно-з повідними територіями - меж ми природного з повідник ( ) “едобори” т н ціон льного природного $n$ рку ( ) “одільські овтри”.

еолого-геоморфологічн $\boldsymbol{x}$ p ктеристик територї. сновою для Н Д Ння певній території ст тусу геоп рку є повнот вивченості їі геолого-геоморфологічної будови з под льшим проведенням інвент риз ції т п спортиз ції об’єктів геосп дщини.

природничій літер турі овтр ми прийнято н зив ти увесь комплекс викопних рифових побудов оділля, проте вони суттєво відрізняються з походженням, літологічним скл дом порід т морфологічними особливостями рельєфу. труктур овтрової зони т к : головне $n$ смо овтрів, сформов не як 6 р'єрний риф у пізньому $б$ дені й перекрите орг ногенними споруд ми р ннього с рм ту; окремі м сиви овтрів (біогерми пізньоб денського віку, які, імовірно, сформув лись у л гун х, більшість з яких розмит бо перекрит молодшими відкл д ми), розт шов ні н схід від головного п см ; окремі т к зв ні бічні товтри (біогерми) р нньос рм тського віку, розт шов ні, перев жно, з хідніше оловного п см ; території колишніх проток $і$ л гун, які відокремлюв ли свого ч су зі сходу і з ходу рифові споруди від суходолу й уздовж яких ч сто течуть суч сні річки оділля; проходи між окремими рифовими м сив ми, ч стин $з$ яких нині з йнят річковими долин ми, ч стин виповнен люві льно-дельтовими т континент льними (лесовими) відкл д ми.

одільські овтри приурочені до окр їни хідноєвропейської пл тформи і повністю розт шов ні н пл тформній основі. рямолінійн форм головного п см овтрів зумовлен регіон льним розломом. ля м сивів головного п см х р ктерні північноз хідні н прями простяг ння, для бічних товтрів - групув ння у лінійні п см північно-східного простяг ння.

оловне п смо збудов не верхньоб денськими орг ногенними т орг ногенно-детритовими в пняк ми, які з ляг ють н відкл д х силуру, верхньої крейди т міоцену (нижньої ч стини розрізу верхнього б дену). ерхньоб денські в пняки лок льно перекриті відкл д ми нижнього с рм ту т четвертинними н гром дженнями. рг ногенні споруди нижнього с рм ту перекрив ють верхньоб денські відкл ди головного п см , т кож простежуються н південний з хід від нього, де утворюють скелясті конусоподібні підняття, які н зив ють бічними товтр ми $[3,5,6]$.

еред викопних орг ногенних споруд одільських овтрів чітко розрізняють головне п смо т окремі товтри. ля головного п см овтрів х р ктерні: 1) вирівнян широк (від 200-300 до 500-700 м) вершинн поверхня; 2) симетричн будов схилів (південно-з хідний схил короткий і крутий (до $35-40^{\circ}$ ), північно-східний - довгий і пологий (до 10-15º; 3) зн чні бсолютні (440-430 м н півночі, 400-415 м у центр льній ч стині т 350-380 м н півдні) т відносні (від 50-60 до 120-140 м у річкових долин х) висоти; 4) високі пок зники горизонт льного розчленув ння рельєфу $\left(3,5-4,0 \mathrm{KM} / \mathrm{KM}^{2}\right)$ у місцях перетину головного п см річковими долин ми т низькі $\left(0,5-1,5 \mathrm{KM} / \mathrm{KM}^{2}\right)$ у меж х вершинних поверхонь.

морфологічними особливостями рельєфу серед бічних товтрів виділяють: 1) високі (до 25-30 м відносної висоти) конусоподібної форми п горби (“товтри”) з крутими (до 30-45 ${ }^{\circ}$ схил ми т численними виход ми в пняків; 2) невисокі (до 5 м відносної висоти) з пологими (до $10-15^{\circ}$ ) схил ми п горби (“могилки”), нечітко вир жені у рельєфі оділля.

інні геолого-геоморфологічні об’єкти пропонов ного геоп рку. днією з умов успішного функціонув ння геоп рку є репрезент тивність т доступність для огляду 
особливо цінних геолого-геоморфологічних об'єктів. роектов ний геоп рк, розт шов ний у меж х одільських овтрів, повинен сприяти збереженню т охороні викопних рифових піднять пізньоб денського т р нньос рм тського віку, скельних виходів рифових в пняків, природних т штучних (к р'єри, штольні) відслонень, печер, к ньйоноподібних ділянок річкових долин, к рстових озер, водосп дів.

риродоохоронні об'єкти, спрямов ні н збереження рельєфу овтрів, з йм ють порівняно незн чну ч стку з кількістю т площею у структурі природно-з повідного фонду території. б'єкти геосп дщини одільських овтрів, з звич й, м ють природоохоронний ст тус геологічних, гідрологічних п м'яток природи, є під охороною у скл ді комплексних т бот нічних п м'яток природи, л ндш фтних, лісових т бот нічних 3 к зників бо розт шов ні в меж $\mathrm{x}$ великоплощинних 3 повідних територій - природного з повідник “ едобори” (9 516,7 г ) т н ціон льного природного п рку “ одільські овтри" (261 316,0 г ).

озглянемо суч сний ст н охорони об’єктів геосп дщини одільських овтрів. ипові ділянки головного п см овтрів охороняють у меж х бот нічних 3 к зників місцевого зн чення (“ обриводський”, “ рочище ож рниця”, “ еребківський”), л ндш фтних 3 к зників з г льнодерж вного (“в нковецький”, “ т нівський”) т місцевого (“ лущинецький”, “ олуп нівськ вят ор ”, “в хновецький”) зн чення, вони м ють ст тус геологічних п м’яток природи (“ ор бин ”, “ ор овбуш ” т ін.). ідкісними для геологічної будови головного п см $\epsilon$ відслонення порід, де в рифових літот мнієвих в пняк х тр пляються колонії кор лів (поблизу сіл ксимівк т лущинці) $[6,9]$. і ділянки головного п см охороняють як геологічні п м'ятки природи “ ид нецькі скелі” т “ ст нці с рм тського моря”.

ля демонстр иії х р ктерних особливостей геологічної будови головного $n$ см

одільських овтрів цінними є ділянки з відслоненнями рифогенних в пняків. території природного з повідник “" едобори” виділяються скелі в н р нк (м сив г. 3 ров , 403,2 м), скелясті уступи у привершинних ч стин х схилів гір нцов (410,2 м) т околих (403,8 м), потужні скелясті н гром дження н вершині г. охіт $(413,9$ м) т г. іряв к лк. меж х “ одільські овтри” скелясті відслонення рифових в пняків спостеріг ють у долин х річок в нчик, мотрич і укш (див. рисунок). кельні комплекси головного п см овтрів м ли т кож с кр льне зн чення - дольмен н г. охіт, скелі в урочищі “ ущ відлюдник” (розт шов ні н території з повідник

“ едобори”), скельний мон стир у меж х ост нця берегового рифу в коті (

“ одільські овтри”).

звемо т кож ділянки головного п см овтрів з потужними товщ ми детритових в пняків, які сформув лись н поч тку м ксим льної верхньоб денської тр нсгресії, коли море поширилось н території не лише ередк рп тської 3 п дини, й олиноодільської плити [3]. отужні товщі детритових в пняків виявлені в периферійних ч стин х 6 денських рифів - поблизу н селених пунктів в нківці (з повідник “ едобори”) т исогірк , ривороття (територія “ одільські овтри”).

пецифічними з погляду морфології рельєфу є місия перерізу головного $n$ cм овтрів річковими долин ми. ереріз ючи головне п смо, річк утворює к ньйон з високими (до 100 м) урвистими схил ми. і відтинки головного п см овтрів охороняють у меж х $з$ повідник “ едобори” (долин р. бруч), л ндш фтних 3 к зників 3 г льнодерж вного зн чення “ в хновецький” (долин р. в нчик) т “" рм люков гор ” (долин p. укш ). 


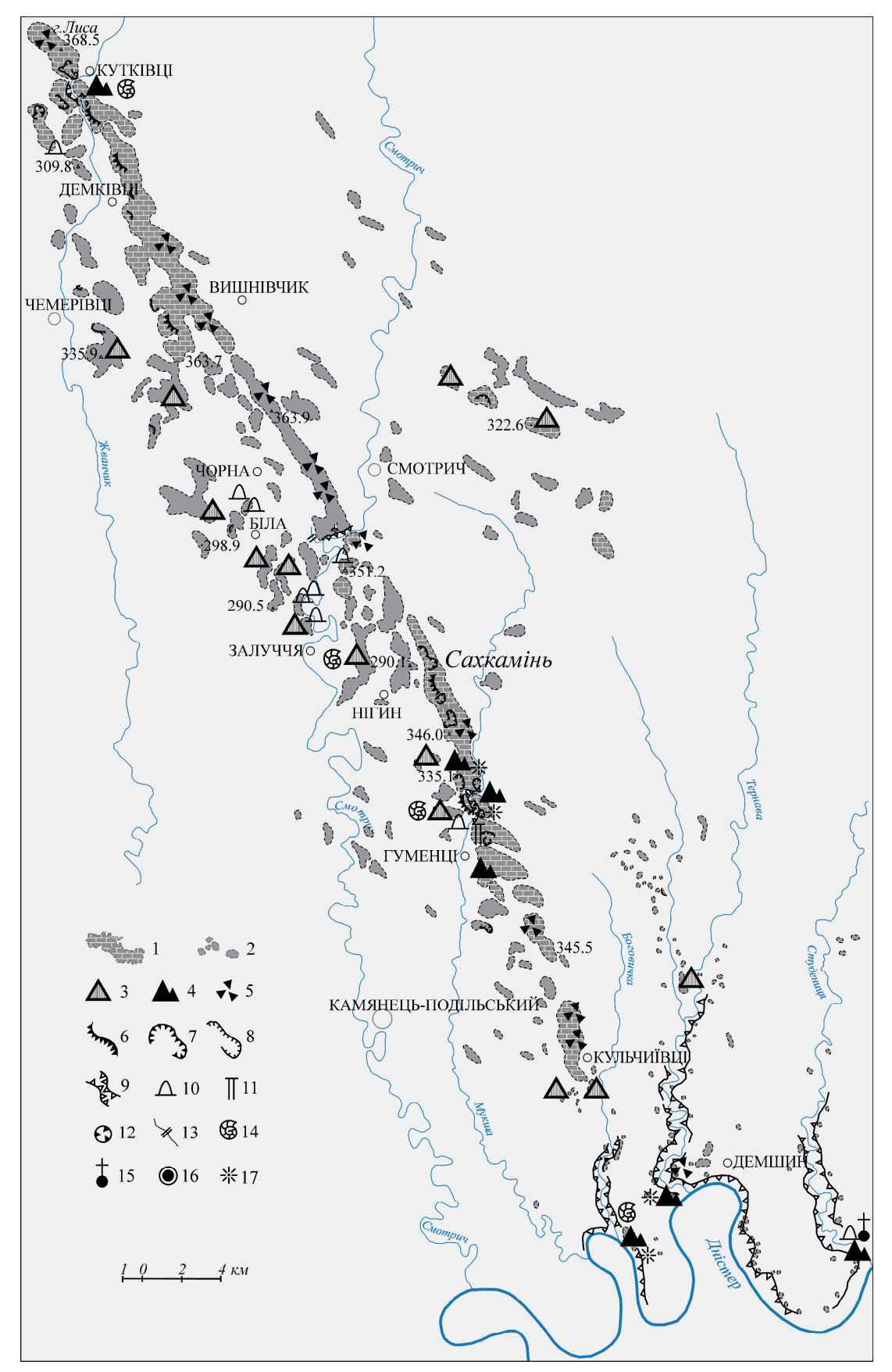

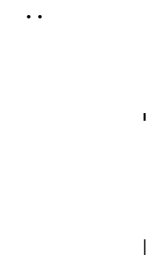

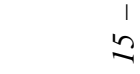

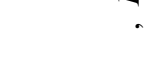

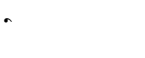

焉总是:-

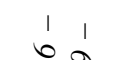

के

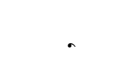

号啫

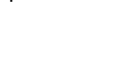

总表

国茥 $1 \pm$

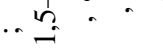

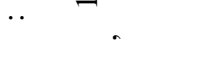

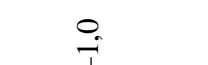

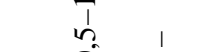

ज0 003

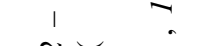

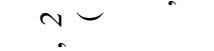

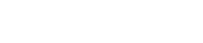

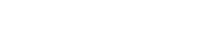

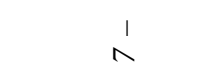

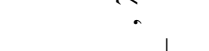

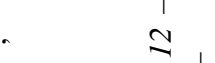

1 1 再

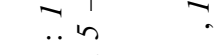

总总它貝

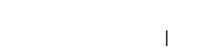

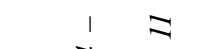

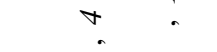

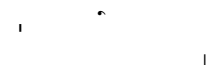

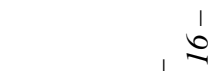

.

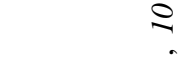


меж х одільських овтрів виділяють т кож $n$ горби-ост нці, які не м ють лінійно витягнутої у північно-з хідному н прямі форми - еред, тинськ і елик уг їх . ору елик уг їх (400,6 м) охороняють у л ндш фтному 3 к знику 3 г льнодерж вного зн чення “ елик і л уг їх ”.

відміну від головного п см , бічні товтри вир жені у рельєфі досить різном нітними 3 морфологією т потужністю рифових відкл дів п горб ми і гребенями. ме бічні товтри створюють неповторний “місячний л ндш фт" н території одільської височини, який прив блює туристів. меж х з повідник “ едобори” бічні товтри предст влені групою м льовничих скелястих п горбів поблизу с. ікно. ут у відслоненнях в пнякових товщ тр пляються молюскові бо молюсково-серпулові череп шники, у яких перев ж ють череп шки к рдіумів з родини Obsoletiforma т Musculus. они з повнюють 3 глибини в серпулово-мікробі літових в пняк х бо утворюють рифовий схил 3 ш рув тих ос дів, н хилених н зовнішній бік рифу $[3,6,9]$. вершини г. остр відкрив ється п нор м н головне п смо (м сив г. 3 ров ) т бічні товтри зюр в , узков, юбовня т ін.

н ціон льному п рку “ одільські овтри” с рм тські орг ногенні побудови, з звич й, об'єдн ні у вир зні скелясті гребені, які розт шов ні перпендикулярно до н пряму простяг ння головного п см овтрів. облизу с. ільховець з зн чені бічні товтри охороняють у меж х бот нічного з к зник “ ільховецькі товтри”. облизу сіл іл т орн створено геологічну п м'ятку природи “овтр ерш к 3 печерою” т л ндш фтний з к зник “ орочинські овтри”. меж х бічних товтрів збереглись цінні ділянки степової рослинності, які охороняють у меж х бот нічних 3 к зників “ ерчецьк товтр ” т “ овтри дов т ернов ”, бот нічної п м'ятки природи з г льнодерж вного зн чення “ овтр мовит”.

воєрідними є бічні товтри поблизу сіл ігин т ербк , які м ють чітко вир жені конусоподібні скелясті вершини, об'єдн ні у гребені. скельно-степову рослинність цих товтрів охороняють у меж х бот нічних 3 к зників “ ігинські товтри” т “ ербецькі товтри".

іж ст нцією купне і долиною р. мотрич бічні товтри предст влені у рельєфі у вигляді пологих п сом, які з морфологічними особливостями рельєфу н г дують головне п смо. я ділянк $є$ унік льною для території овтрів, оскільки лише тут головне п смо формують відкл ди нижнього с рм ту.

літер турних джерел відомо, що в меж х головного п см овтрів розт шов ні $n e$ чери (поблизу сіл ропотов , ишнівчик, купне, іл ). роте доступною для огляду з відповідним спорядженням є лише печер ерлин в урочищі ущ н території з повідник “ едобори”.

о об'єктів геоморфологічної сп дщини з числяємо т кож гідрологічні об'єкти, де геоморфологічний чинник відігр є в жливу роль $[1,4,8]$. території овтр можн н зв ти озерця ікнини поблизу сіл ікно т олуп нівк, джерел в урочищі ліпий яр т водосп д н лівій притоці р. мотрич поблизу сел р чківці.

ік вими для озн йомлення з геологічною будовою одільських овтрів $є з$ кинуті промислові кр’ери, у яких відкриті товщі б денських т с рм тських рифових в пняків. йбільше к р'єрів зосереджено в меж х північної т південної ч стин овтрів. роте більшість к р'єрів діє, вн слідок чого повністю бо ч стково руйнуються окремі м сиви овтрів. меж х оловного п см промислові розробки вели і підземним способом - у штольнях ( в нковецькі т уменецькі штольні). 
тже, унік льні т типові для одільських овтрів геолого-геоморфологічні об'єкти охороняють у скл ді комплексних т бот нічних п м'яток природи, вони розт шов ні н території л ндш фтних, лісових т бот нічних з к зників бо м ють ст тус геологічних п м'яток природи.

сторико-культурн сп дщин території геоп рку. меж х одільських овтрів розт шов ні цік ві рхітектурні т рхеологічні п м'ятки - з мки в б р жі, к л ті, д вні городищ , зн хідки стоянок д вніх людей. с. ринцилів зберігся один з д вніх видів діяльності - вип люв ння в Пн в примітивних печ х (в пнярк х). г. охіт було к пище, н якому стояв язичницький ідол “ вітовид”. епер тут руїни к пищ т зруйнов ний дольмен. схил х г. охіт виявлено чотири поселення-супутники святилищ , жителі яких обслуговув ли потреби жерців т проч н. е одне поселення “ бин долин "- розт шов не н схилі ліпого яру. д ними рхеологічних розкопок, проведених н уковим співробітником ернопільського кр єзн вчого музею . годинською, це було селище ремісників-гонч рів $[4,7,8]$.

хідніше одільських овтрів розт шов не місто м'янець- одільський, яке щороку відвідують тисячі туристів. льовничі кр євиди одільських овтр, їхній б г тий природний потенці л створюють сприятливі передумови для розвитку туризму в регіоні. кскурсії потрібно проводити орг нізов но з уч стю “ одільські овтри” т

“ едобори”, що д сть змогу уникнути нег тивного рекре ційного впливу т зберегти цінні й унік льні природні комплекси одільських овтрів.

еотуристичні об'екти досліджув ної території. явність унік льних природних т споруджених людиною об'єктів створюють сприятливі умови не лише для оздоровчого (у меж х овтрів розміщені с н торії), і для пізн в льного, ктивного туризMy.

“ едобори” т “ одільські овтри” ктивно співпр цюють з орг ніз ціями екологічного спрямув ння, університет ми т школ ми. меж х з повідник діють три н уково-пізн в льні стежки, у н ціон льному п рку спл нов ні одно- т кільк денні пішохідні, велосипедні т кінні м ршрути. оряд з груповими екскурсіями збільшується кількість екскурсій для невеликої (до п’яти осіб) кількості людей. $\quad$ к тенденція є позитивною, оскільки зменшує нтропогенне н в нт ження н екологічні стежки [7].

меж х “ едобори” діють еколого-пізн в льні стежки - “ гору остр ”, “ гору охіт” т “ о пущі ідлюдник”. ідвідув ння відбув ється обов'язково в супроводі пр цівників з повідник , режим стежок “ гору остр ” “ “ гору охіт” передб ч $є$ обмеження кількості відвідув чів т н д ння перев ги окремим їхнім к тегоріям (н уковцям, студент м).

ериторією “ одільські овтри” проходить декільк екотуристичних м ршруmів (піших, кінних), які передб ч ють озн йомлення з геологічною будовою т морфологічними особливостями овтрів. екре ційну діяльність н території н ціон льного природного п рку орг нізовують спеці льні підрозділи дміністр ції п рку, т кож інші підприємств, уст нови т орг ніз ції н підст ві угод 3 дміністр цією . ункціонують т кі м ршрути:

- дводенний піший м ршрут, який почин ється поблизу смт емерівці, проходить 3 лісненими овтр ми до с. ишнівці, потім у зворотному н прямі до смт емерівці;

- дводенний кінний м ршрут довжиною 50 км, який почин ється у м. м'янецьодільський, проходить через сел олосків, удлівці, в лля і з вершується н

в нецькій турб зі. уристи озн йомлюються з цік вими форм ми рельєфу одільських овтрів - головним п смом т бічними товтр ми, з печерою “ тл нтид ”; 
- триденний кінний м ршрут довжиною 70 км, який почин ється у м. м'янець- одільський, проходить біля рм люкової гори, с. упруньківці, через долину р. ерн в , через сел одільське, $б$ нівк, брикосівк до смт т р шиця;

- триденний кінний природничо-л ндш фтний м ршрут довжиною 80 км, почин ється з м. м'янець- одільський, проходить через з к зник “ рм люков гор ”, д лі об біч товтрів “ отири к в лери” (с. ербк ), ігинських овтр (с. ігин) до с. р чківці. уристів т кож озн йомлюють з бічними товтр ми окіл, мовит, ерченськ . лі м ршрут проходить через сел іл , орн до смт емерівці;

- кільк денний (з поб ж нням уч сників) велосипедний м ршрут довжиною 30 40 км (до 100 км), почин ється від смт емерівці, проходить через сел $\quad$ бинці, $\quad$ в лля, ривороття із вершується у с. в нець (с йт ).

уристичні фірми (зокрем , “ кс мит ”, “ ерр нкогніт ”) пропонують т кі niзн в льні туристичні екскурсї [8]:

- “ о сел ікно”- одноденн пішохідн екскурсія околицями “ едобори”, як передб ч є відвід ння екологічної стежки “ гору остр ” т геологічної п м’ятки природи “ келі в н р нк”;

- “ о пущі ідлюдник” - дводенн пішохідн подорож територією 3 повідник “ едобори” т “ одільські овтри”. ндрівк охоплює відвідув ння екологічних стежок “ о пущі ідлюдник ” т “ гору охіт”, штучного водосп дун р. бруч поблизу смт т нів, околиної скелі. овжин м ршруту ст новить 20-25 км;

- “ о пущі ідлюдник т в нковецьких штолень”- триденн пішохідн подорож територією з повідник “ едобори” т “ одільські овтри”. ндрівк передб ч є відвідув ння екологічних стежок “ о пущі ідлюдник ” т “ гору охіт”, спуск у печеру “ерлин” т з кинутих в нковецьких штолень. овжин м ршруту ст новить 25-30 KM.

тже, основою для формув ння геоп рку “ кр їнські ( одільські) овтри” є передусім природний з повідник “ едобори” і н ціон льний природний п рк “ одільські овтри”. геоп рк повинні увійти унік льні для одільської височини форми структурно-денуд ційного рельєфу, сформов ні вн слідок відпреп рув ння 6 р'єрного рифу і біогермів міоценового віку. ерспективним для одільських овтрів є розвиток орг нізов ної рекре ції, зокрем , н уково-пізн в льного, спортивно-оздоровчого т гротуризму. екре ційний вектор розвитку господ рюв ння н території одільських отврів $\epsilon$ необхідною умовою збереження їхньої геолого-геоморфологічної сп дщини.

1. інько . . ослідження, охорон т використ ння геоморфологічної сп дщини н великопросторових з повідних територіях хідної кр їни / . . інько // існ. ьвів. ун-ту. ер. геогр. - 2006. - ип. 33. - .99-111.

2. інько . . ередумови створення геоп рку “ кр їнські овтри”/ . . інько, . . евчук // хорон і менеджмент об'єктів неживої природи н з повідних територіях : м тері ли міжн р. н ук.-пр кт. конф. [“ хорон і менеджмент об'єктів неживої природи н з повідних територіях”], ( рим йлів, 21-23 тр в. 2008 р.). - рим йлів ; ернопіль : жур , 2008. - .94-99.

3. н менськ . . овтровий кряж т його місце у структурі івденно- хідної окр їни хідновропейської пл тформи / . . н менськ // еол. журн. - 1976. - .36. ип. 5. - . 54-62.

4. плун . . еоп рк як модель збереження т оптим льного природокористув ння одільських овтр / . . плун, . . еболд // хорон і менеджмент об'єктів неживої природи н 3 повідних територіях : м тері ли міжн р. н ук.-пр кт. конф. [“” хорон і менеджмент об'єктів нежи- 
вої природи н 3 повідних територіях"], ( рим йлів, 21-23 тр в. 2008 р.). - рим йлів ; ернопіль : жур , 2008. - . 121-126.

5. оролюк . . одольские олтры и условия их обр зов ния / . . оролюк // руды н-т геологических н ук ер. геол. - 1952. - ып. 110. - № 56. - . 9-120.

6. их йлов . . рогнозно-геологическ я оценк известняков олтровой гряды к к сырья для р зличных отр слей промышленности / . их йлов // тчет о р бот х проведенных в 19671971 гг. - ., 1971. - 194 с.

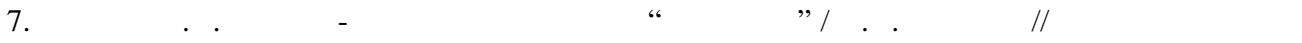
природоохоронної діяльності лісового з повідник (н прикл ді природного з повідник “ едобори"). - ьвів: полом, 2006. - . 306-313.

8. евчук . . икорист ння геолого-геоморфологічної сп дщини природного 3 повідник “ едобори” для популяриз ції н ук про емлю / . . евчук, . . урськ , . . ліяр // хорон і менеджмент об'єктів неживої природи н з повідних територіях : м тері ли міжн p. н ук.-пр кт. конф. [“ хорон і менеджмент об'єктів неживої природи н 3 повідних територіях”], ( рим йлів, 21-23 тр в. 2008 р.). - рим йлів ; ернопіль: жур , 2008. - .328-331.

9. Jasionowski M. Budowle serpulowo-mikrobialitowe sarmatu na Roztoczu: niezwykle joint-venture / M. Jasionowski // Przegl. Geol. - 1996. - Vol. 44. - S. 1044-1048.

10. European Geopark Network. - ежим доступу до джерел : www.europeangeoparks.org.

11. UNESCO Geoparks Programme - a new initiative to promote a global network of geoparks safeguarding and developing selected areas having significant geological features // Hundred and fifty-sixth Session. United Nations Educational, Scientific and Cultural Organization: Executive Board. Paris, 1999. S. 1-4. - ежим доступу до джерел : http://unesdoc.unesco.org/images/0011/001151/115177e.pdf]

m ття: н дійшл до редколегї 02.11.2011 прийнят до друку 22.11.2011

\section{THE PERSPECTIVES OF GEOPARK CREATION AT PODILLIAN TOVTRY REGION}

\section{Brusak, K. Moskalyuk}

Ivan Franko National University of Lviv, . Doroshenko St., 41, UA - 79000 Lviv, Ukraine, e-mail: brusak_vitaliy@ukr.net, zolotynka@ukr.net

The possibilities of forming new international category of geoheritage preserving - geopark in Tovtry region has been discussed. The geology-geomorphologic structure of Podillian Tovtry has been described and the inventory of valuable geology-geomorphologic objects - the base of preplanned geopark creation, has been proposed. The list of geotouristic objects and the perspectives for development of educational forms of tourism in the Tovtry has been analyzed.

Key words: geology-geomorphologic objects, geoheritage, geopark, Global Geoparks Network, European Geoparks Network, fossil reef, Podillian Tovtry. 


\section{- рус к, - оск люк \\ ввовский н цион льный университет имени в н р нко, \\ ул. . орошенко, 41, г. ввов, 79000, кр ин}

ссмотрено возможность созд ния т территории олтр междун родной к тегории сохр нения геон следия - геоп рк . х р ктеризиров но геолого-геоморфологическое строение территории одольских олтр и определено ценные геолого-геоморфологические объекты, которые ст нут основой проэктируемого геоп рк . ведено перечень геотуристических объектов н территории исследов ний и предложено пути р звития позн в тельных форм туризм в предел х олтр.

лючевые слов : геолого-геоморфологический объект, геон следие, геоп рк, лоб льн я сеть геоп рков, вропейськ сеть геоп рков, ископ емый риф, одольськие олтры. 